\title{
PENGARUH N-3 HUFA PAKAN TERHADAP PERTUMBUHAN BENIH KERAPU MACAN, Ephinepelus fuscoguttatus
}

\author{
Ketut Suwirya, Nyoman Adiasmara Giri, dan Muhammad Marzuqi
}

\begin{abstract}
ABSTRAK
Asam lemak n-3 HUFA adalah esensial bagi ikan-ikan laut. Kebutuhan asam lemak n-3 HUFA pada ikan berbeda menurut jenis dan ukuran ikan. Percobaan ini dilaksanakan untuk mengetahui kebutuhan n-3 HUFA pakan bagi pertumbuhan dan efisiensi pakan benih ikan kerapu macan. Ikan percobaan berukuran 5,08 $\pm 0,72 \mathrm{~g}$ dipelihara pada kepadatan 12 ekor dalam bak ukuran $100 \mathrm{~L}$ dengan sistem air mengalir selama 9 minggu. Pakan percobaan berupa pelet kering dengan kandungan n-3 HUFA berbeda yaitu $0,0 \% ; 0,5 \% ; 1,0 \% ; 1,5 \% ; 2,0 \%$; dan $2,5 \%$. Hasil percobaan menunjukkan bahwa kandungan n-3 HUFA dalam pakan mempengaruhi pertumbuhan dan efisiensi pakan $(P<0,05)$. Kandungan $n-3$ HUFA pakan sebesar 2,0\% dapat menghasilkan pertumbuhan dan efisiensi pakan yang baik pada ikan ukuran $5,08 \mathrm{~g}$. Pertumbuhan ikan yang diberi pakan dengan kandungan n-3 HUFA $0,0 \% ; 0,5 \% ; 1,0 \% ; 2,0 \%$; dan $2,5 \%$ berturut-turut adalah $508,7 \% ; 527,6 \% ; 559,9 \% ; 605,4 \% ; 620,8 \%$; dan $650,1 \%$.
\end{abstract}

\begin{abstract}
Effect of dietary n-3 HUFA on growth of tiger grouper, Ephinepelus fuscoguttatus juvenile. By: Ketut Suwirya, Nyoman Adiasmara Giri, and Muhammad Marzuqi

A group of n-3 HUFA is essential for marine fish. Requirement of n-3 HUFA for fish depends on species and size of fish. This experiment was conducted to know the requirement of dietary n-3 HUFA growth and feed efficiency of tiger grouper, Ephinepelus fuscoguttatus juvenile. Juveniles with average body weight of $5.08 \pm 0.72 \mathrm{~g}$ were reared in $100 \mathrm{~L}$ tank with flow-through system for 9 weeks. The levels of $n-3$ HUFA in the test diets were $0.0 \%, 0.5 \%, 1.0 \%, 1.5 \%, 2.0 \%$, and $2.5 \%$. Result of the experiment showed that dietary n-3 HUFA affected growth and feed efficiency of tiger grouper juvenile. The level of n-3 HUFA in diet to support good growth and feed efficiency tiger grouper juvenile of $5.08 \mathrm{~g}$ in size was $2.0 \%$. The growth gained of fish fed with diets containing $0.0 \%, 0.5 \%, 1.5 \%, 2.0 \%$, and $2.5 \%$ n-3 HUFA were $508.7 \%, 527.6 \%, 559.9 \%, 605.4 \%, 620.8 \%$, and $650.1 \%$ respectively.
\end{abstract}

KEYWORDS: $\quad$ tiger grouper dietary, n-3 HUFA, feed, growth

\section{PENDAHULUAN}

Saat ini penelitian pembenihan kerapu macan, Ephinepelus fuscoguttatus dilakukan secara intensif dan perkembangan hasilnya cukup menggembirakan. Sejalan dengan hal tersebut, penelitian pakan buatan pada kerapu juga perlu dilakukan dalam antisipasi perkembangan budi dayanya.

Lemak adalah komponen pakan yang merupakan sumber energi dan asam lemak esensial untuk menunjang pertumbuhan ikan red sea bream (Vergara et al., 1996), dan kadar lemak dalam pakan berpengaruh terhadap pertumbuhan ikan red drum (Williems \& Robinson, 1988). Di samping itu yang tidak kalah pentingnya dari lemak adalah kadar dan komposisi asam lemak dari sumber lemak yang digunakan dalam pakan.
Kebanyakan ikan air laut hanya mempunyai kemampuan yang terbatas untuk mensintesis $n-3$ HUFA dari asam lemak n-3 rantai karbon yang lebih pendek (Owen et al., 1975). Asam lemak n-3 HUFA seperti 20:5n-3 (EPA) dan 22:6n-3 (DHA) merupakan asam lemak esensial bagi kebanyakan ikan laut (Yano \& Fujii, 1975; Fujita et al., 1980; Watanabe et al., 1983; Izquierdo et al., 1989; Webster \& Lovell, 1990; Suwirya et al., 2001). Kekurangan n-3 HUFA mengakibatkan tingkat kematian larva yang tinggi dan pertumbuhan yang lambat, serta tidak sempurnanya pembentukan dan fungsi gelembung renang pada larva ikan (Sorgeloos et al., 1988; Webster \& Lovell, 1990; Koven et al., 1990). Oleh karena itu, penelitian asam lemak tersebut dilakukan untuk melengkapi informasi dalam pengembangan pakan buatan untuk menunjang budi daya ikan kerapu macan. Tujuan penelitian ini

Peneliti pada Balai Besar Riset Perikanan Budidaya Laut, Gondol 
adalah untuk melihat pengaruh asam lemak n-3 HUFA pakan terhadap pertumbuhan yuwana kerapu macan.

\section{BAHAN DAN METODE}

Pada percobaan ini dibuat enam pakan dengan sumber lemak berbeda yaitu minyak oleik (18:0), dan minyak dengan n-3 HUFA tinggi (40\% n-3 HUFA). Adapun komposisi minyak yang digunakan sebagai sumber n-3 HUFA adalah sebagai berikut: asam miristik (14:0) 3,5\%; asam palmitat (16:0) $23,5 \%$; asam palmitoloik (16:1n-9) 3,9\%; asam oleik (18:0) $15,4 \%$; asam linoleat $(18: 3 n-3) 3,6 \%$; asam arachidonat (20:4n-6) 3,2\%; EPA (20:5n-3) 9,1\%; dan DHA $(22: 6 n-3) 30,9 \%$. Sebelum membuat pakan, bahan yang kandungan lemaknya tinggi seperti tepung rebon, hati cumi, dan ikan dikeluarkan lemaknya dengan metode Bligh \& Dyer (1959). Adapun formulasi dan hasil analisis pakan percobaan tertera pada Tabel 1. Kandungan $n-3$ HUFA dari masing-masing pakan adalah $0,0 \% ; 0,5 \% ; 1,0 \% ; 1,5 \% ; 2,0 \%$; dan $2,5 \%$. Pakan dibuat dalam bentuk pelet, dikeringkan dengan freeze dryer, dan disimpan pada suhu $4^{\circ} \mathrm{C}$ sebelum dipakai dan selama percobaan.

Percobaan ini menggunakan benih kerapu macan dengan bobot awal 5,08 $\pm 0,72$ gram. Ikan dipelihara dalam bak-bak polietilen volume $100 \mathrm{~L}$ dengan kepadatan 12 ekor/bak dengan sistem air mengalir. Aliran air diatur pada debit $200 \mathrm{~mL}$ per menit. Suhu dan salinitas air media pemeliharaan selama percobaan adalah $28--30^{\circ} \mathrm{C}$ dan $31--33$ ppt. Pemberian pakan 2 kali per hari dan setiap pemberian pakan diamati secara seksama sampai semua ikan tidak mau makan lagi. Sisa pakan yang tidak termakan dikumpulkan dan dikeringkan untuk menentukan

Tabel 1. Komposisi pakan percobaan (\%)

Table 1. Composition of test diets (\%)

\begin{tabular}{|c|c|c|c|c|c|c|}
\hline \multirow{2}{*}{$\begin{array}{c}\text { Bahan } \\
\text { Ingredient }\end{array}$} & \multicolumn{6}{|c|}{$\begin{array}{l}\text { Kandungan n-3 HUFA pakan } \\
\text { Level of dietary n-3 HUFA (\%) }\end{array}$} \\
\hline & 0.0 & 0.5 & 1.0 & 1.5 & 2.0 & 2.5 \\
\hline Kasein (Casein) & 24 & 24 & 24 & 24 & 24 & 24 \\
\hline Tepung ikan (Fish meal) & 33.0 & 33.0 & 33.0 & 33.0 & 33.0 & 33.0 \\
\hline Tepung cumi (Squid meal) & 5 & 5 & 5 & 5 & 5 & 5 \\
\hline Tepung rebon (Tiny shrimp meal) & 2.2 & 2.2 & 2.2 & 2.2 & 2.2 & 2.2 \\
\hline Oleik (Oleic acid) & 9.0 & 7.75 & 6.50 & 5.25 & 4.00 & 2.75 \\
\hline Powers & 0.0 & 1.25 & 2.50 & 3.75 & 5.00 & 6.25 \\
\hline Campuran mineral (Mineral mix $)^{1}$ & 2.5 & 2.5 & 2.5 & 2.5 & 2.5 & 2.5 \\
\hline Campuran vitamin (Vitamin mix $)^{2}$ & 1.3 & 1.3 & 1.3 & 1.3 & 1.3 & 1.3 \\
\hline Dekstrin (Dextrin) & 19.8 & 19.8 & 19.8 & 19.8 & 19.8 & 19.8 \\
\hline Glucan & 0.1 & 0.1 & 0.1 & 0.1 & 0.1 & 0.1 \\
\hline Astaksantin (Asthaxantin) & 0.1 & 0.1 & 0.1 & 0.1 & 0.1 & 0.1 \\
\hline CMC & 3.0 & 3.0 & 3.0 & 3.0 & 3.0 & 3.0 \\
\hline Total & 100 & 100 & 100 & 100 & 100 & 100 \\
\hline \multicolumn{7}{|l|}{ Proksimat (Proximate): } \\
\hline Protein & 50.81 & 50.55 & 50.70 & 50.49 & 50.60 & 50.67 \\
\hline Lemak (Lipid) & 9.53 & 9.47 & 9.61 & 9.52 & 9.51 & 9.54 \\
\hline Abu $(A s h)$ & 8.23 & 8.13 & 7.96 & 7.97 & 7.73 & 7.90 \\
\hline Serat (Fibre) & 1.70 & 2.15 & 1.58 & 2.19 & 1.75 & 1.92 \\
\hline Kadar air (Moisture) & 3.92 & 3.84 & 4.38 & 3.82 & 3.66 & 3.78 \\
\hline $\begin{array}{l}\text { Energi (Kkal/g pakan) } \\
\text { Energy (Kcal/g feed) }\end{array}$ & 4.99 & 4.97 & 5.00 & 4.98 & 5.00 & 4.99 \\
\hline
\end{tabular}

Mineral mix (mg/100 g pakan/feed): $\mathrm{KH}_{2} \mathrm{PO}_{4} 412, \mathrm{CaCO}_{3} 282, \mathrm{Ca}\left(\mathrm{H}_{2} \mathrm{PO}_{4}\right) 618, \mathrm{FeCl}_{3} 4 \mathrm{H}_{2} \mathrm{O} 166, \mathrm{ZnSO}_{4} 9.99$, $\mathrm{MnSO}_{4} 6.3, \mathrm{CuSO}_{4} 2$,

$2 \mathrm{CoSO}_{4} \cdot 7 \mathrm{H}_{2} \mathrm{O} 0.05, \mathrm{KJ} 0.15$, Dextrine 450, Cellulose 553,51

3 Vitamin mix (mg/100 g pakan) (Vitamin mix: $\mathrm{mg} / 100 \mathrm{~g}$ diet): thiamin- $\mathrm{HCl} \mathrm{5.0;} \mathrm{riboflavin} \mathrm{5.0;} \mathrm{Ca-pantothenate}$ 10.0 ; niacin 2.0; pyridoxine- $\mathrm{HCl} 4.0$; biotin 0.6 ; folic acid 1.5 ; cyanocobalamin 0.01 ; inositol 200.0; $p$-aminobenzoic acid 5.0; menadion 4.0; b-caroten 15.0; calciferol 1.9; a-tocoferol 20.0; cholin chloride 900.0. 
jumlah pakan yang dikonsumsi. Jumlah pakan yang diberikan per hari dihitung dengan melihat selisih bobot pakan sebelum dan sesudah pemberian pakan. Kotoran dalam bak dibersihkan setiap pagi hari sebelum pemberian pakan. Percobaan dirancang menggunakan rancangan acak lengkap dengan lima perlakuan dan tiap perlakuan terdiri atas tiga ulangan.

Percobaan ini berlangsung selama 9 minggu. Setiap 2 minggu sampai minggu ke-8 dan 1 minggu pada minggu terakhir dilakukan pengukuran bobot tubuh untuk melihat perkembangannya. Penimbangan dilakukan terhadap semua ikan dalam setiap bak secara individu. Data pertumbuhan, konsumsi pakan, dan efisiensi pakan dianalisis menggunakan sidik ragam dan beda antar perlakuan diuji dengan LSD pada taraf nyata $95 \%$.

\section{HASIL DAN BAHASAN}

Hasil pengamatan pertambahan bobot benih kerapu macan selama percobaan dari masing-masing perlakuan terlihat pada Gambar 1. Pada ikan yang diberi pakan dengan kandungan n-3 HUFA 0,0\% terlihat pertambahan bobotnya tertinggal setelah hari ke-56 dibandingkan dengan ikan yang diberi pakan dengan kandungan n-3 HUFA 0,5\%; 1,0\%; 1,5\%; $2,0 \%$; dan $2,5 \%$. Hal ini menunjukkan bahwa n-3 HUFA sangat penting bagi pertumbuhan yuwana ikan kerapu macan.

Pertambahan bobot tubuh, efisiensi, dan konsumsi pakan benih kerapu macan pada akhir percobaan disajikan pada Tabel 2. Dari Tabel 2 terlihat bahwa kandungan n-3 HUFA dalam pakan berpengaruh nyata $(P<0,05)$ terhadap pertumbuhan benih kerapu macan.
Pada percobaan ini sintasan ikan mencapai 100\% pada akhir percobaan untuk semua perlakuan. Pertambahan ikan tertinggi $(650,1 \pm 13,7 \%)$ diperoleh pada ikan yang diberi pakan dengan kandungan n-3 HUFA 2,5\%. Ikan kerapu yang diberi pakan dengan kandungan n-3 HUFA 0,5\% sampai $1,5 \%$ tidak berbeda nyata $(P>0,05)$; namun ikan yang diberi pakan dengan kandungan n-3 HUFA 2,0\% memberikan pertumbuhan yang lebih tinggi dari ikan yang diberi pakan dengan kandungan n-3 HUFA 0,0\% sampai 1,0\% $(P<0,05)$. Pakan dengan kandungan n-3 HUFA 2,0\% dan 2,5\% tidak menghasilkan pertumbuhan yang berbeda nyata $(P>0,05)$. Hal ini menunjukkan bahwa kandungan $n-3$ HUFA pakan yang optimal untuk pertumbuhan ikan kerapu macan adalah $2,0 \%$. Percobaan ini juga menunjukkan bahwa kekurangan n-3 HUFA dalam pakan kerapu macan akan menyebabkan terhambatnya pertumbuhan.

Peningkatan n-3 HUFA dalam pakan dapat meningkatkan efisiensi pakan yuwana ikan kerapu bebek (Tabel 2). Kandungan n-3 HUFA 1,5\% dalam pakan (IV) yang diberikan pada yuwana ikan kerapu macan memberikan efisiensi pakan lebih tinggi dibandingkan dengan pakan yang mengandung $0,0 \%$ $n-3$ HUFA $(P<0,05)$, namun efisiensi pakan dari ikan yang diberi pakan dengan kandungan $n-3$ HUFA $0,0 \%$ sampai $1,0 \%$ tidak berbeda nyata $(P>0,05)$. Ikan yang diberi pakan dengan kandungan n-3 HUFA $1,5 \%$ sampai $2,5 \%$ memberikan efisiensi pakan yang sama (Tabel 2). Hasil pengamatan ini menunjukkan bahwa n-3 HUFA perlu mendapat perhatian dalam memformulasi pakan ikan kerapu macan agar efisien dalam penggunaan pakan. Asam lemak n-3 HUFA umumnya

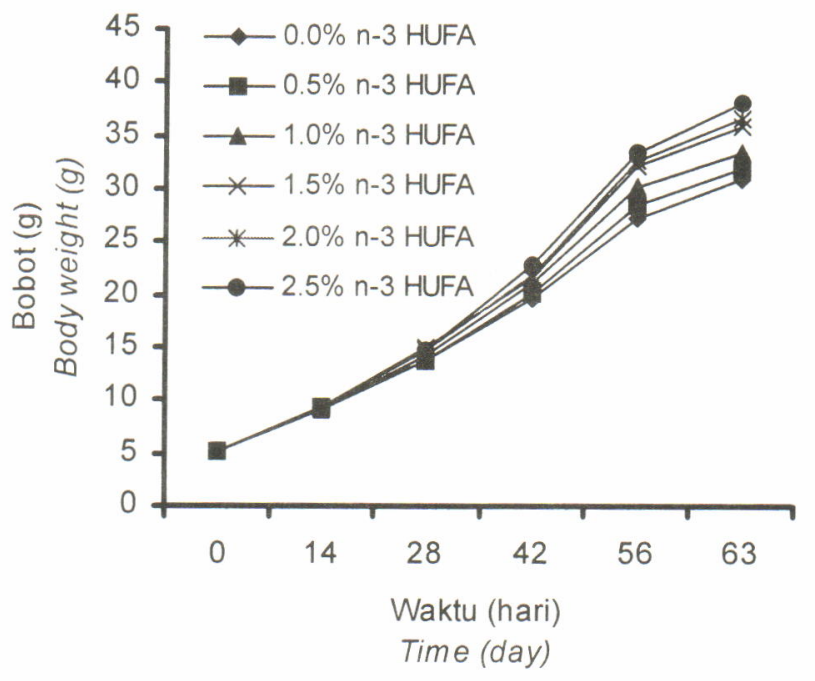

Gambar 1. Bobot yuwana kerapu macan diberi pakan dengan kandungan n-3 HUFA yang berbeda selama percobaan

Figure 1. Body weight of tiger grouper juvenile fed diets with different of level dietary n-3 HUFA during the experiment 
Tabel 2. Pertumbuhan, efisiensi penggunaan, dan konsumsi pakan yuwana kerapu macan yang diberi pakan dengan kandungan n-3 HUFA yang berbeda

Table 2. Weight gain, feed efficiency ratio, and feed intake of juvenile tiger grouper fed with diets with different levels of $n-3$ HUFA

\begin{tabular}{cccc}
\hline $\begin{array}{c}\text { Kandungan n-3 HUFA pakan } \\
\text { Dietary n-3 HUFA (\%) }\end{array}$ & $\begin{array}{c}\text { Kenaikan bobot } \\
\text { Weight gain }(\%)\end{array}$ & $\begin{array}{c}\text { Efisiensi pakan } \\
\text { Feed efficiency (\%) }\end{array}$ & $\begin{array}{c}\text { Konsumsi pakan } \\
\text { Feed intake (g/ind.) }\end{array}$ \\
\hline 0.0 & $508.7+10.3^{\mathrm{a}}$ & $0.71^{\mathrm{a}}$ & $15.22+1.06^{\mathrm{a}}$ \\
0.5 & $527.6+29.4^{\mathrm{ab}}$ & $0.74^{\mathrm{ab}}$ & $16.11+0.32^{\mathrm{a}}$ \\
1.0 & $559.9+11.9^{\mathrm{ab}}$ & $0.79^{\mathrm{ab}}$ & $15.65+0.69^{\mathrm{a}}$ \\
1.5 & $605.4+50.6^{\mathrm{bc}}$ & $0.80^{\mathrm{b}}$ & $15.21+0.27^{\mathrm{a}}$ \\
2.0 & $620.8+27.0^{\mathrm{c}}$ & $0.86^{\mathrm{b}}$ & $14.81+2.62^{\mathrm{a}}$ \\
2.5 & $650.1+13.7^{\mathrm{c}}$ & $0.85^{\mathrm{b}}$ & $15.00+2.78^{\mathrm{a}}$ \\
\hline
\end{tabular}

Nilai tengah dengan huruf yang sama pada kolom tidak berbeda secara statistik $(P<0,05)$

Means with the same superscript in columns are not statistically different $(P<0.05)$

diperoleh dari minyak ikan atau organisme laut lainnya. Karena kebutuhan n-3 HUFA ikan kerapu macan relatif rendah, maka lemak pakan dapat disusun dari beberapa sumber lemak seperti minyak ikan, minyak cumi, dan minyak nabati dengan perbandingan tertentu. Hal ini tentunya sangat bergantung pada kandungan n-3 HUFA sumber lemak yang digunakan.

Konsumsi pakan per individu benih ikan kerapu macan selama percobaan tidak dipengaruhi oleh kandungan n-3 HUFA (Tabel 2). Ini berarti bahwa yuwana kerapu macan dapat menerima semua pakan yang digunakan dalam percobaan ini.

Beberapa peneliti melaporkan bahwa n-3 HUFA adalah esensial untuk ikan-ikan laut, karena ikan laut mempunyai kemampuan yang terbatas untuk menyintesis n-3 HUFA di dalam tubuhnya (Owen et al., 1975;
Kanazawa et al., 1979; Ostrowski \& Davakaran, 1990). Kebutuhan n-3 HUFA ikan bergantung pada jenis dan ukuran ikan. Kebutuhan n-3 HUFA larva ikan gilthead sea bream adalah 2,05\%-2,16\% (Salhi et al., 1994), yuwana ikan red drum adalah 0,5\%-1,0\% (Lochmann \& Gatlin, 1993), ikan Korean rockfish dengan bobot $5,9 \mathrm{~g}$ adalah sekitar 0,9\% (Lee et al., 1993), dan 1,4\% untuk yuwana kerapu bebek (Suwirya et al., 2001).

Kandungan n-3 HUFA dalam pakan juga mempengaruhi kadar n-3 HUFA dalam lemak tubuh ikan kerapu macan (Tabel 3). Makin tingginya kadar n-3 HUFA pakan akan meningkatkan kadar n-3 HUFA dalam lemak tubuh kerapu macan. Dari Tabel 3 terlihat bahwa kerapu macan yang diberi pakan dengan kandungan $n-3$ HUFA 0,$0 ; 0,5 ; 1,0 ; 1,5 ; 2,0 ;$ dan $2,5 \%$ selama 9 minggu maka kandungan n-3 HUFA lemak

Tabal 3. Komposisi asam lemak tubuh ikan kerapu macan yang diberi pakan dengan kandungan n-3 HUFA yang berbeda

Table 3. Fatty acid composition of tiger grouper body fed with containing diets different levels of dietary n-3 HUFA

\begin{tabular}{|c|c|c|c|c|c|c|}
\hline \multirow{2}{*}{$\begin{array}{l}\text { Asam lemak } \\
\text { Fatty acid }\end{array}$} & \multicolumn{6}{|c|}{$\begin{array}{c}\text { Kadar n-3 HUFA pakan } \\
\text { Level of dietary n-3 HUFA (\%) }\end{array}$} \\
\hline & 0.0 & 0.5 & 1.0 & 1.5 & 2.0 & 2.5 \\
\hline Miristik (Myristic acid) $(14: 0)$ & 5.54 & 4.05 & 3.71 & 2.09 & 4.61 & 2.74 \\
\hline Palmitat $(P a / m i t a t e)(16: 0)$ & 29.96 & 34.68 & 26.87 & 20.16 & 36.74 & 33.52 \\
\hline Palmitoleat (Palmitoleic acid) (16:1n-9) & 20.78 & 20.54 & 13.42 & 10.17 & 14.63 & 18.02 \\
\hline Oleat (Oleic acid) $(18: 1 n-9)$ & 18.82 & 15.54 & 9.51 & 8.17 & 7.57 & 8.99 \\
\hline Linolenat (Linolenic acid) $(18: 3 n-3)$ & 20.60 & 20.15 & 32.05 & 40.17 & 22.54 & 20.04 \\
\hline Arasidonat (Arachidonate acid) $(20: 4 n-$ & 1.24 & 0.28 & 2.02 & 3.79 & 0.73 & 1.04 \\
\hline EPA $(20: 5 n-3)$ & 0.88 & 1.09 & 2.56 & 3.55 & 4.45 & 4.53 \\
\hline $\mathrm{DHA}(22: 6 n-3)$ & 1.78 & 2.81 & 3.86 & 5.20 & 5.79 & 6.23 \\
\hline $\mathrm{NN}^{*}$ & 0.40 & 0.86 & 0.00 & 7.70 & 3.88 & 4.90 \\
\hline Total n-3 HUFA & 2.66 & 3.90 & 6.42 & 9.75 & 10.24 & 10.76 \\
\hline
\end{tabular}

* Asam lemak yang tidak dapat diidentifikasi (Unidentified fatty acid) 
Tabel 4. Hasil analisis proksimat tubuh ikan kerapu macan pada akhir percobaan

Table 4. Proximat analysis of tiger grouper body at the end of experiment

\begin{tabular}{|c|c|c|c|c|c|}
\hline \multirow{2}{*}{$\begin{array}{c}\text { n-3 HUFA pakan } \\
\text { Level of dietary n-3 } \\
\text { HUFA (\%) }\end{array}$} & \multicolumn{5}{|c|}{ Komposisi tubuh (Body composition) } \\
\hline & $\begin{array}{l}\text { Protein } \\
\text { Protein (\%) }\end{array}$ & $\begin{array}{l}\text { Lemak } \\
\text { Lipid }(\%)\end{array}$ & $\begin{array}{c}\text { Abu } \\
\text { Ash (\%) }\end{array}$ & $\begin{array}{c}\text { Serat } \\
\text { Fibre (\%) }\end{array}$ & $\begin{array}{c}\text { BETN/ } \\
N \text {-free extract (\%) }\end{array}$ \\
\hline 0.0 & $62.26 \pm 2.37^{a}$ & $15.90 \pm 0.83^{a}$ & $17.79 \pm 0.63^{a}$ & $1.96^{a}$ & $3.41^{a}$ \\
\hline 0.5 & $62.71 \pm 1.84^{\mathrm{a}}$ & $14.45 \pm 2.41^{a}$ & $17.48 \pm 0.86^{a}$ & $2.04^{\mathrm{a}}$ & $3.13^{a}$ \\
\hline 1.0 & $61.85 \pm 2.12$ & $14.86 \pm 1.39^{a}$ & $17.94 \pm 1.37^{a}$ & $1.86^{\mathrm{a}}$ & $3.45^{\mathrm{a}}$ \\
\hline 1.5 & $61.12 \pm 0.42$ & $15.50 \pm 0.46^{a}$ & $16.80 \pm 0.31^{a}$ & $2.17^{a}$ & $4.28^{a}$ \\
\hline 2.0 & $62.79 \pm 0.42$ & $14.63 \pm 0.80^{a}$ & $17.59 \pm 0.89^{a}$ & $2.47^{a}$ & $3.82^{a}$ \\
\hline 2.5 & $61.39 \pm 1.28$ & $14.51 \pm 0.28^{a}$ & $17.40 \pm 0.62^{a}$ & $2.04^{\mathrm{a}}$ & $3.13^{a}$ \\
\hline
\end{tabular}

tubuhnya berturut-turut 2,$66 ; 3,90 ; 6,42 ; 9,75 ; 10,24$; dan $10,76 \%$. Pola yang hampir sama tampaknya terjadi pada larva ikan ekor kuning, Seriola quinqueradiata bahwa larva yang diberi pakan dengan kandungan $n$ 3 HUFA lebih tinggi akan menyebabkan kandungan n-3 HUFA lemak tubuhnya menjadi lebih tinggi (Furuita et al., 1996).

Hasil analisis proksimat tubuh ikan kerapu yang diberi pakan dengan kadar $n-3$ HUFA $0,0 \% ; 0,5 \%$; $1,0 \% ; 1,5 \% ; 2,0 \%$; dan $2,5 \%$ disajikan pada Tabel 4 . Tabel 4 menunjukkan bahwa kadar n-3 HUFA pakan tidak mempengaruhi kadar protein, lemak, dan abu tubuh ikan kerapu macan yang diberi pakan dengan kadar $n-3$ HUFA yang berbeda.

\section{KESIMPULAN}

Kandungan n-3 HUFA dalam pakan benih ikan kerapu macan dapat meningkatkan pertumbuhan dan efisiensi pakan. Kandungan n-3 HUFA yang optimal dalam pakan dengan kadar lemak berkisar $9,41 \%-$ $9,61 \%$ adalah $2,0 \%$.

\section{DAFTAR PUSTAKA}

Bligh, E.G. and W.J. Dryer. 1959. A rapid method of total lipid extraction and purification. Canadian J. Biochem. Physiol., 37: 911--917.

Fujita, S., T. Watanabe, and C. Kitajima. 1980. Nutrition quality of artemia from different location as living feed from viewpoint of essential fatty acids for marine fish. In G. Personne, P. Sorgeloos, O. Roels, and E. Jespers (Eds.). The Brine Shrimp Artemia, Universa Press, Belgium. 3: 277--290

Furuita, H., T. Takeuchi, T. Watanabe, H. Fujimoto, S. Sekiya, and K. Imaizumi. 1996. Requirement of larval yellowtail for eicosapentaenoic acid, docosahexaenoic, and n-3 highly unsaturated fatty acid. Fisheries Science, 62(3): 372--379.

Izquierdo, M.S., T. Watanabe, T. Takeuchi, T. Arakawa, and C. Kitajima. 1989. Requirement of larvae red sea bream, Pagrus major for essential fatty acids. Nippon Suisan Gakkaishi, 55: 859--867.
Kanazawa, A., S. Teshima, and K. Ono. 1979. Conversion of linoleic to $n-3$ highly unsaturated fatty acid in marine fishes and rainbow trout. Bull. Jpn. Soc. Sci. Fish., 46: 1.231--1.233.

Koven, M.W., A. Tandler, G.W. Kissil, D. Sklan, O. Frieslander, and M. Harel. 1990. The effect of dietary n-3 polyunsaturated fatty acid on growth, survival, and swim bladder development in Sparus aurata larvae. Aquaculture, 91: 131--141.

Lee, S.M., J.Y. Lee, Y.J. Khang, H.D. Yoon, and S.B. Hur. 1993. n-3 HUFA requirement of Korean rockfish, Sebastes Schlegeli. Bull. Korean Fish. Soc. 26 (5): 477--492.

Lochmann, R.T. and D.M. Gatlin. 1993. Essential fatty acids requirement of juvenile red drum (Sciaenops ocellatus). Fish Physiol. Biochem., 12: 221--235.

Owen, J.M., J.W. Adron, C. Middleton, and C.B. Cowey. 1975. Elongation and desaturation of dietary fatty acid in Turbot (Scopthalamun maximus) and rainbow trout. Lipid, 10: 258--271.

Ostrowski, A.C. and S. Davakaran. 1990. Survival and bioconversion of $n-3$ fatty acid during early development of dolpin (Corypaena hyppuras) larvae fed oilenriched rotifer. Aquaculture, 89: 273--285.

Salhi, M., M.S. Izquierdo, C.M. Hernandez, M. Gonzalez, and Fernandez-Palacois. 1994. Effect of lipid and n3 HUFA levels in microdeits on growth, survival, and fatty acid composition of larval gilthead sea bream (Sparus aurata). Aquaculture, 124: 275--282.

Sorgeloos, P., P. Leger, and P. Laveus. 1988. Improved larval rearing of European, Asian seabass, seabream, mahi-mahi, siganid, and milkfish using enriched diets for rotifer and Artemia. World Aquacult., 19: 78--79.

Suwirya, K., N.A. Giri, dan M. Marzuqi. 2001. Pengaruh n3 HUFA terhadap pertumbuhan dan efisiensi pakan yuwana ikan kerapu bebek, Cromileptes altivelis. In Sudradjat, A., E.S. Heruwati, A. Poernomo, A. Rukyani, J. Widodo, dan E. Danakusuma (Eds.). Prosiding Teknologi Budi Daya Laut dan Pengembangan Sea Farming di Indonesia. p. 201--206.

Vergara, J.M., L. Ropbiana, M. Izquierdo, and M.D.L. Higuera. 1996. Protein sparing effect of lipid in the diets for fingerlings of gilthead se bream. Fish. Sci, 62(4): 624628. 
Watanabe, T., C. Kitajima, and S. Fujita. 1983. Nutritional values of live organisms used in Japan for mass propagation of fish: a review. Aquaculture, 34: 115--143.

Webster, C.D. and R.T. Lovell. 1990. Respone of stripped bass larvae fed brine shrimp from different sources containing different fatty acids compositions. Aquaculture, 90: 49--61.
Williems, C.D. and E.H. Robinson. 1988. Respone of red drum to various dietary levels of manhaden oil. Aquaculture, 70: 107--120.

Yano, Y. and M. Fujii. 1975. Studies on nutrition of red sea bream IX: Effect of n-3 fatty acid supplement in acorn oil diet on growth and feed efficiency. Bull. Jpn. Soc. Sci. Fish., 41: 73--77. 